\title{
A cidade e o mar: considerações sobre a memória das relações entre Fortaleza e o ambiente litorâneo
}

RESUMO: Este trabalho analisa a relação entre Fortaleza e o Mar, notadamente a Praia de Iracema, na formação da cultura marítima da capital cearense. Trata-se de que forma o fortalezense encarou e encara as transformações que ocorrem na atual conjuntura do litoral. Como ferramenta de apoio, foram empreendidos levantamentos cartográficos a fim de verificar o modo de expansão do movimento dialético entre o homem e o mar no município, dando ênfase para os mapeamentos produzidos por Adolfo Herbster e Simões de Farias. A partir das análises realizadas na área em estudo, percebeu-se que desde a tomada da população às práticas marítimas modernas de lazer, o litoral fortalezense vem passando por sucessivas transformações no que concerne aos seus usos e funções.

\section{The city and the sea: considerations on the memory of the relationship between Fortaleza and coastal environment}

\begin{abstract}
This paper analyzes the relationship between in the Fortaleza with the Sea, notably the Iracema Beach, the formation of the maritime culture in Fortaleza. This is how the Fortaleza faced and face the changes that occur in the current climate of the coast. As a support tool, cartographic surveys were undertaken to verify the mode of expansion of the dialectical movement between man and the sea in the city, with emphasis on the maps produced by Adolfo Herbster and Simões de Farias. From the analysis performed in the study area, we noticed that since taking the population to modern practices maritime leisure, the Fortaleza coast has undergone successive transformations with respect to its uses and functions.
\end{abstract}

Fábio de Oliveira Matos*

* Mestre em Geografia pela Universidade Estadual do Ceará (UECE). Doutorando do Programa de Pós-Graduação em Geografia da Universidade Federal do Ceará (UFC).

Palavras-chave: Geografia Urbana; Memória; Cartografia; Litoral; Fortaleza.

Key-words: Urban Geography; Memory; Cartography; Coast; Fortaleza. 


\section{Introdução}

Este trabalho propõe apresentar sob a ótica geohistórica um panorama das relações da cidade de Fortaleza com as práticas marítimas modernas empregadas na Praia de Iracema, observando o processo de valorização daquele pedaço do litoral que, desde o início do século $X X$, vem passando por sucessivas transformações. Para tanto, foi realizado um levantamento nos registros cartográficos do município, visando retratar o relacionamento da espacialidade da cidade com o mar.

Percebe-se a importância da referida praia para o despertar do fortalezense para o mar, iniciada na década de $1920 \mathrm{com}$ a tomada das práticas marítimas (banhos de mar, banhos de sol etc.) advindas da Europa. A população da capital cearense, que outrora não mantinha relações com o marítimo, passa a perceber o mar como uma nova área de lazer da cidade, dando singularidade a Praia de Iracema como local para as novas práticas de lazer que emergiam àquela época.

Essa valorização dos espaços litorâneos, ocorrida na capital cearense, nos levou a analisar 0 acordar da população para o mar, bem como das políticas públicas implementadas para o desenvolvimento dessa porção do litoral. A Praia de Iracema foi à área selecionada para a pesquisa por a mesma ser alvo de constantes intervenções do Poder Público, o que proporciona o surgimento de novos frequentadores, a partir dessa intervenção do Estado por intermédio de alocação de equipamentos de lazer nesse espaço. Esta pesquisa é fruto do projeto $\mathrm{O}$ Centro de Fortaleza, realizado no Laboratório de Planejamento Urbano e Regional (LAPUR) do Departamento de Geografia da Universidade Federal do Ceará.

\section{A expansão urbana de Fortaleza: a cidade de costas para o mar}

${ }^{1}$ A Zona-da-mata começava a se dedicar ao cultivo da cana-deaçúcar, cabendo ao Ceará a venda dos produtos pecuários para a região. Dessa forma, é dado início a movimentação econômica interna no território cearense.

Geografia Ensino \& Pesquisa, v. 15, n.1, p. 71-84 jan./abr. 2011

A cidade e o mar: considerações sobre a memória das relações entre Fortaleza e o ambiente litorâneo
Do ponto de vista histórico, Fortaleza teve seu crescimento urbano voltado em direção ao sertão. A faixa litorânea fortalezense passa dessa forma alguns séculos sendo ignorada pelos seus citadinos. 0 mar, ponto de início da colonização cearense, vem configurar-se nos primórdios do crescimento da cidade, como um local ad fora de Fortaleza.

Este curioso fato de rejeição do fortalezense ao mar deu-se principalmente pela origem daqueles que chegaram. Fortaleza, até 1799 (ano do desmembramento do Ceará da Província de Pernambuco) era uma vila sem importância econômica. Destacavam-se naquela época as vilas de Aracati, Icó, Sobral, Crato, Camocim, Acaraú e Quixeramobim. Isso se dava pelo motivo da principal atividade econômica da província ser a pecuária, com a exportação de carne, couro e animais de tração para a Zona-da-mata nordestina1.

Fortaleza vem crescer justamente a partir da elite oriunda do interior da província. Dessa forma, o mar passa a se configurar por muitos anos como um local esquecido, ausente de qualquer tipo de interesse do homem. Se utilizando das plantas históricas de Fortaleza, esta pesquisa vem analisar a expansão urbana da cidade, verificando as mudanças de olhares do fortalezense em relação ao mar e observando a tomada da ocupação do litoral. Para tanto foram selecionadas, dentre tantas plantas e cartas que retratam a cidade, algumas que veem destacar o progresso da ocupação do espaço fortalezense. São elas: a) a Primeira Planta da Cidade de Fortaleza, de 1726 e desenhada pelo Capitão-mor do período, Manuel Francês; b) a Planta da Cidade de Fortaleza, datada de 1850 e organizada pelo coordenador da Câmara 
Municipal, Antônio Simões Ferreira de Farias; e c) a Planta Topográfica de Fortaleza e Subúrbios, de 1875, elaborada por Adolfo Herbster, nome de grande destaque na história da forma urbis fortalezense.

Analisando a consolidação de Fortaleza enquanto capital, Dantas (2002) afirma que a cidade nascera voltada para o sertão, contradizendo sua natureza litorânea, dado as relações no campo cultural e econômico da sociedade com o interior do Estado, configurando-se dessa forma como uma cidade litorâneo-interiorana.

O litoral passa a ser vislumbrado pela sociedade fortalezense quando em busca de uma vida político-econômica mais independente, a cidade apresenta-se como ponto de exportação dos produtos produzidos no Ceará, notadamente 0 charque e 0 algodão, através do Porto, implantado em fins do século XVIII, nas intermediações da Praia do Peixe, atual Praia de Iracema.

A oferta de mercadorias para o exterior já era presente desde meados do século XVII nas principais cidades brasileiras, uma vez que vendiam seus produtos para a Europa e outras capitanias. Nesse período o comércio do Brasil dava seus primeiros passos. 0 comércio de ouro movimentava cidades mineiras e paulistas, a cafeicultura exportadora expande-se pela Baixada Fluminense, indo até o sul de Minas, seguindo o Vale do Parnaíba até penetrar em território paulista.

Fortaleza não se inseria nesse novo modelo econômico que se iniciava no país. A vila encontrava-se ainda sem infraestrutura básica para o surgimento da economia de exportação vigente em outras capitais. A ausência de um porto em Fortaleza, capaz de exportar os produtos produzidos no Ceará, levava o crescimento de outras localidades, portuárias, como Aracati e Acaraú, passando a colocar o Ceará na rota de exportação do algodão.

Essa precariedade infraestrutural de Fortaleza é percebida a partir da análise da Primeira Planta da Cidade de Fortaleza, rascunhada em 1726 por Manuel Francês (Figura 1) que apresenta a Fortaleza do início do século XVIII.

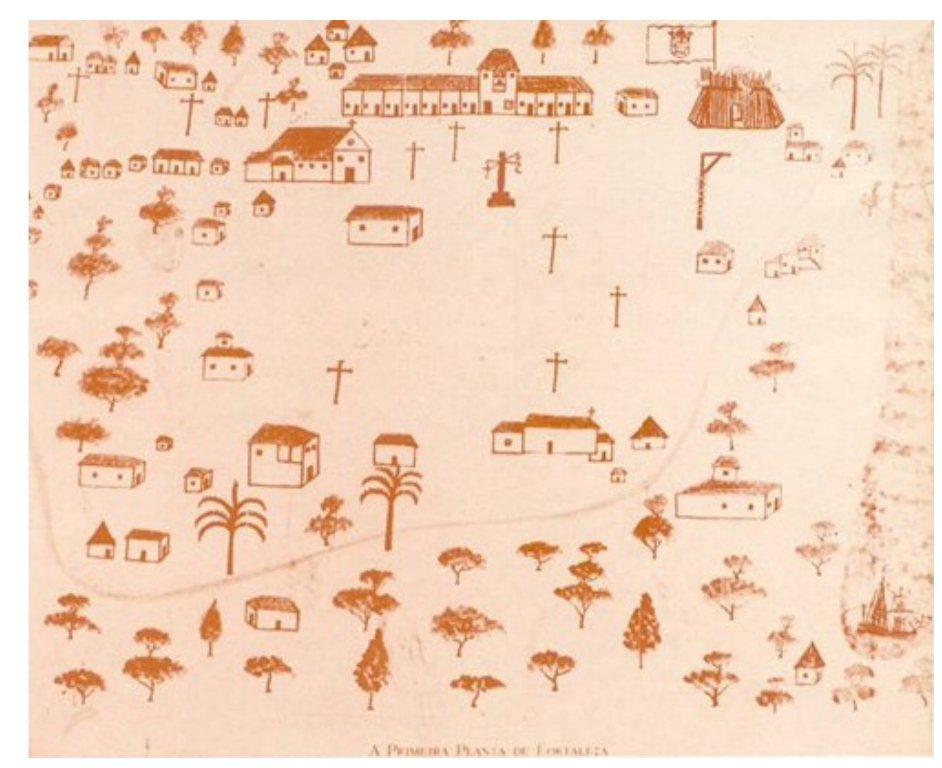

Figura 1 - Primeira Planta da cidade de Fortaleza (1726)

Fonte: Arquivo Nirez.

Geografia Ensino \& Pesquisa, v. 15, n.1, p. 71-84, jan./abr. 2011

Fábio de Oliveira Matos 
o forte e as dez cruzes espalhadas pelo desenho, com o objetivo de reforçar a dominação católica no local, vem como uma tentativa de mostrar características que favorecessem a elevação da Fortaleza de Nossa Senhora da Assumpção à categoria de cidade.

Percebem-se nessa planta as poucas edificações presentes em Fortaleza, que contava com algumas dezenas de casas ainda não arruadas, o forte (ainda de madeira), uma igreja e um mercado. Nota-se a provável inexistência do sobrado localizado a leste do riacho Pajeú, dado pelo fato de não haver nenhum relato que afirme a existência do mesmo e por ser um local apático à ocupação fortalezense da época. Essa construção serviria apenas como uma alusão ao crescimento de Fortaleza, proposto pelo capitão-mor ao reinado português.

0 desinteresse pelo litoral já era percebido, dado pelas poucas edificações na área. Quase cem anos após a planta de Manuel Francês, o viajante inglês Henry Koster, em 1810, relatava a ainda precária estrutura da cidade. No seu relato, intitulado Viagens ao nordeste do Brasil (KOSTER, 2002) dizia ele que a cidade fora edificada sobre terreno arenoso, em formato quadrangular, com quatro ruas partindo da praça e mais outra bem larga, do lado norte desse quadrado, correndo paralelamente, mas sem conexão.

O viajante afirmava também que a cidade possuía três igrejas, uma fortaleza, um mercado e uma repartição de correio. 0 porto era frágil, o comércio fraco, as casas térreas (reforçando a inexistência do desenho de Manuel Francês), as ruas sem calçamento. Segundo Costa (2005) a população na época era de aproximadamente de 1200 moradores.

Embora Fortaleza possuísse a função de capital administrativa da capitania, a cidade não estava inserida no eixo da economia cearense. Esta por sua vez, era baseada no binômio gado-algodão. Tanto o desenvolvimento destas atividades como a indústria do charque, foi responsável pelo surgimento e expansão de vilas em diferentes pontos do Ceará: Icó (1738), Aracati (1748), Sobral (1773), Quixeramobim (1789) (LEMENHE, 1991).

Fortaleza permanece sem expressão na economia local até a segunda metade do século XIX, quando surge como ponto favorável à exportação do algodão cearense para a Europa, permitida pela construção do sistema ferroviário, ligando os polos produtores à capital.

\section{Contribuições de Simões de Farias e Adolfo Herbster na análise da relação entre a cidade e o mar}

Com a construção das linhas de vapores, que percorriam várias cidades do interior com destino à capital, estabelecendo o surgimento de relações econômicas e sociais do sertão com a capital. Outro fator favorecedor dessa ligação foi a construção do porto nas proximidades da Prainha (atual Praia de Iracema). Nesse sentido, Fortaleza toma um novo rumo.

Na segunda metade do século XIX, Fortaleza toma de Aracati, responsável até então pela exportação dos produtos cearenses, o comando das relações comerciais de boa parte do Vale do Jaguaribe e Sertão Central, devido o estabelecimento das linhas de vapores diretamente para a capital. Segundo Souza (1995) muitas vilas se desenvolvem com a instalação das vias férreas, como exemplo tem-se as cidades de Cedro, Acopiara, Reriutaba, Nova Russas, Cariré, Baixio, Capistrano, entre outras.

0 crescimento de Fortaleza deve-se então ao progresso do cultivo do algodão no sertão 
interior, com a expansão da rede ferroviária, que vai atingindo as mais distantes localidades do interior do Estado, como Baturité, Quixadá, Crato, Sobral e Crateús (SILVA, 1992).

Mesmo com a queda na procura do produto brasileiro, devido a entrada dos Estados Unidos no comércio da fibra, o algodão cearense, por sua qualidade, se manteve no mercado, favorecido ainda pela abertura dos portos em 1808, permitindo o comércio direto com Londres, e o surgimento do barco a vapor, diminuindo o tempo das viagens e assim o custo com os transportes, aumentando o volume de comercialização.

A centralização do poder político e administrativo iniciado no primeiro reinado, que favoreceu o crescimento econômico e a hegemonia urbana de Fortaleza, contribuiu também para a ocorrência da maior parte de investimentos governamentais em edificações, infraestrutura e serviços na capital.

A respeito da evolução por que passava Fortaleza, Linhares (1992) destacava a economia pastoril, a economia agrícola e a hegemonia econômica e político-administrativa da cidade como sendo os momentos mais importantes na análise do processo de consolidação da mesma enquanto centro hegemônico, e que vai determinar, a partir da segunda metade do século XIX, os traços fundamentais de sua urbanização.

A planta da cidade de Fortaleza de 1850 (Figura 2) organizada por Antônio Simões Ferreira de Farias e há muito perdida, reencontrada nos dias atuais por José Liberal de Castro, vem reforçar a expansão da cidade para longe do litoral. A área litorânea mostrava uma ocupação irregular, quase espontânea, indicado no desenho de modo um tanto confuso, fato que teria motivado a contratação de Farias para organizar uma outra planta unicamente referida aquela parte da cidade (CASTRO, 2005).

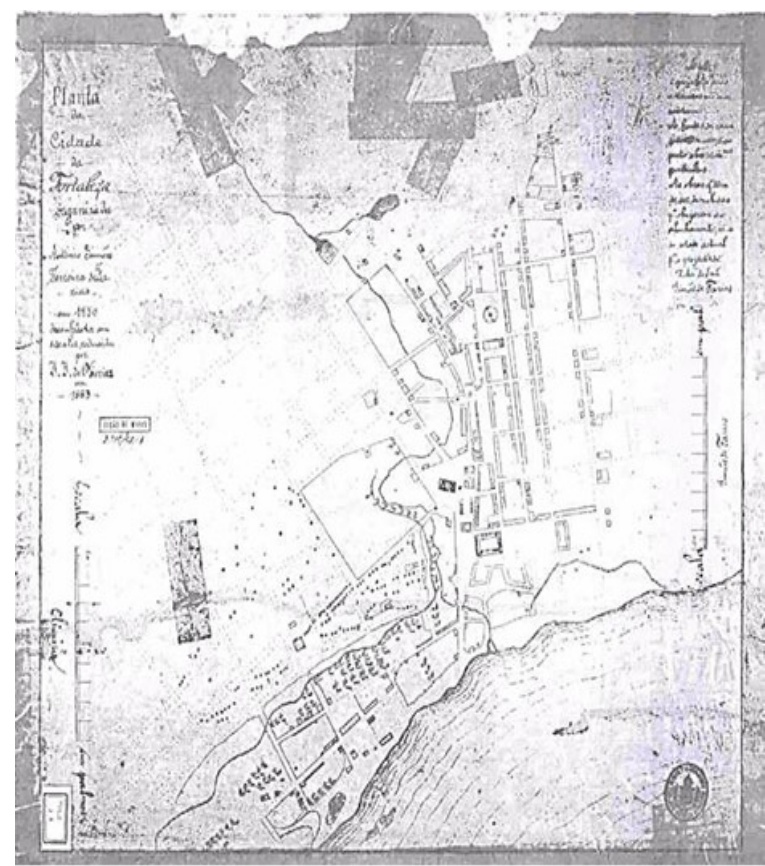

Figura 2 - Planta da cidade de Fortaleza de 1850. Fonte: Castro, 2005

Nota-se também que o riacho Pajeú continuava a constituir uma barreira física à expansão para o leste, embora já estivesse aberta a rua do Norte (atual Governador Sampaio), delineada por Paulet no começo do século. Percebe-se também o pontilhado (proposição urbanística de Simões de Farias), indicando o traçado de ampliação oriental da

Geografia Ensino \& Pesquisa, v. 15, n.1, p. 71-84, jan./abr. 2011

Fábio de Oliveira Matos 
cidade. A planta de 1850 refletia, assim, um clima de expectativa de progresso, subjacente no imaginário da população. Sobre a expansão prevista para o leste da cidade, Castro (2005, p. 151) diz que:

\begin{abstract}
A fim de tentar executar a expansão prevista para o leste da cidade, Farias tomou, como eixo de montagem da nova malha a rua do Norte (rua Governador Sampaio). Nada se sabe, aliás, sobre o que teria levado Paulet no começo do século à abertura da rua do Norte, implantada isoladamente em sítio alheio à malha continua por ele próprio formulada. Também não se explica porque a rua do Norte, denominação conferida a logradouro situado na parte oriental da cidade! Talvez porque se aponta para o Norte, todavia, de modo aproximado, de resto, como as demais "ruas" da trama ortogonal.
\end{abstract}

A rua Governador Sampaio passava a servir naquela época como eixo direto de um futuro crescimento de Fortaleza para o leste. Observando a planta de Simões percebe-se também um caminho cruzando o riacho próximo a foz. Essa estrada que vem ligar o litoral oeste do riacho Pajeú ao litoral a leste do mesmo vem a ser a estrada do Meireles (Mucuripe). Essa estrada, um simples caminho arenoso, atuais Rufino de Alencar e Monsenhor Tabosa, encontrava-se com uma capela (Conceição da Prainha), cujas obras, iniciadas uma década antes, ainda estavam por completar. Desse ponto, a estrada continuava para o leste, atingindo o Meireles, de onde prosseguiu até o Mucuripe, desviando-se das dunas (CASTRO, 2005).

No detalhamento da planta de 1850 (Figura 3), onde se destaca a Prainha, nota-se a predominância da paisagem natural, composta por dunas e lagoas interdunares, tendo como sinal de ocupação a Fortaleza de Nossa Senhora da Assunção, o quartel da Fortaleza, a tesouraria provincial e a alfândega (capitania dos portos).

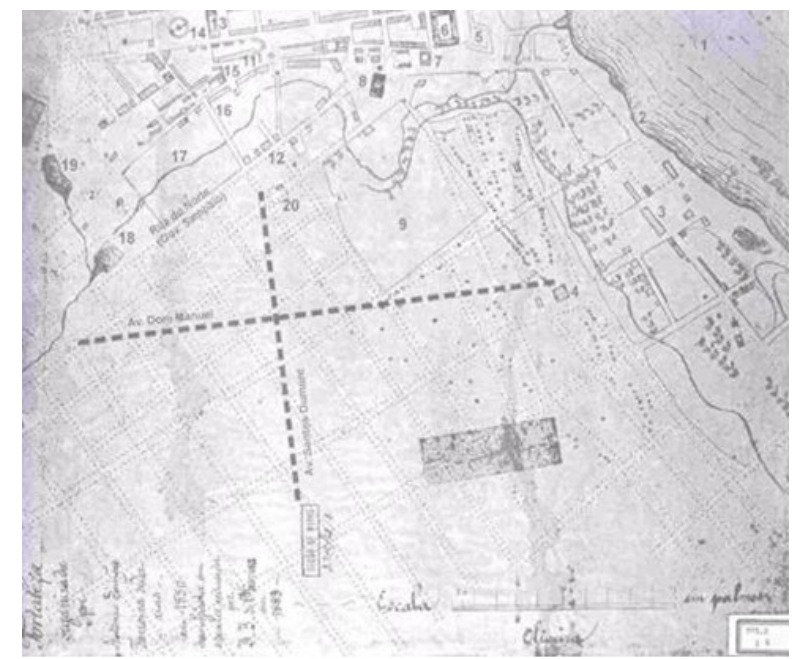

Figura 3 - Ampliação da Planta de 1850 (destaque para a região leste da cidade). Fonte: Castro, 2005.

$O$ fato de a cidade instalar-se no litoral permanecia sem contar muito na formação do imaginário social dos seus habitantes. Segundo Barroso (1912) o imaginário interiorano continuava a se legitimar por toda Fortaleza, até mesmo aqueles imóveis localizados à beiramar, faziam referência a presença do homem do sertão e de seus utensílios. 
As zonas de praia em Fortaleza caracterizam-se nesse período como área de escoamento dos esgotos da cidade, vindo a ser ocupada somente em fins do século XIX, com o surgimento das favelas, devido ao aumento do contingente de imigrante pobres do sertão.

Com Fortaleza apontando como centro político-econômico do Estado, ela passa a despertar 0 interesse da elite cearense para a fixação de moradia. A urbanização de Fortaleza é também favorecida pela vinda dessa elite, pois com ela surge a necessidade de melhorias infra-estruturais e de serviços na capital.

Percebe-se o incremento de equipamentos urbanos em Fortaleza, como a construção de um novo cemitério, a criação da Academia Francesa, a iluminação a gás carbono, entre outros. Surge também a Planta Topográfica de Fortaleza e Subúrbios (Figura 4), de autoria do engenheiro Adolfo Herbster. Integrante da diretoria de obras de Pernambuco, Herbster é cedido ao Governo Provincial do Ceará em 1855, sendo contratado pela municipalidade fortalezense. Dois anos depois, sendo solicitado para a elaboração de plantas da cidade. 0 urbanista traça um plano urbanístico de desenvolvimento para a cidade, dado pela necessidade de expansão àquela época, devida o aumento de sua população².

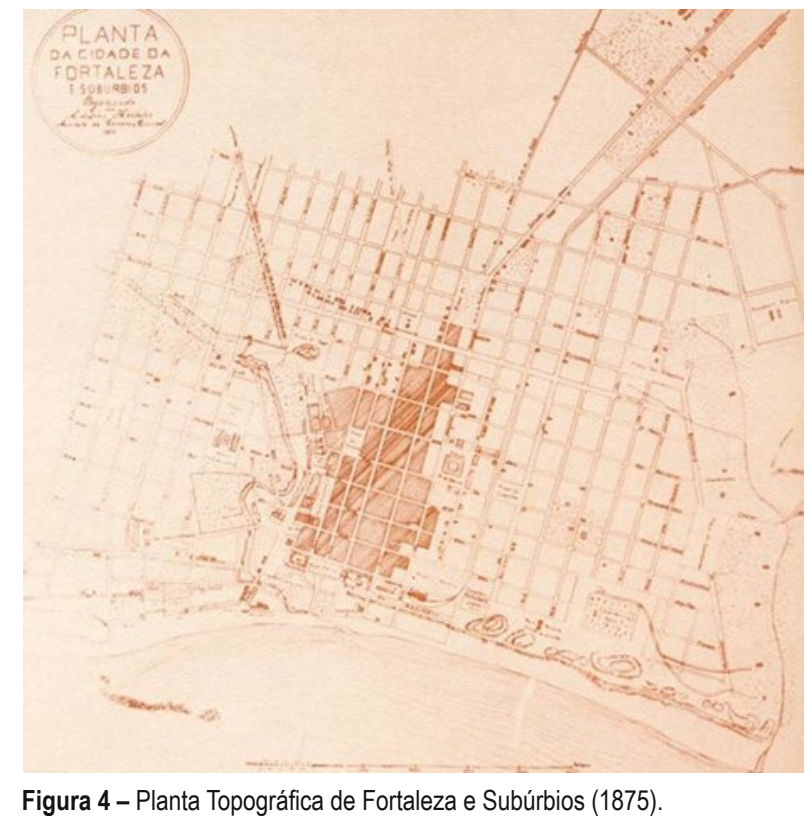

Fonte: Arquivo do Museu da Imagem e do Som.

A referida planta possui um traçado xadrez com grandes boulervards, imitando o modelo parisiense implantado pelo Barão de Haussman, e já idealizado para as ruas da capital cearense cinquenta anos antes de Herbster, por Silva Paulet (LINHARES, 1992).

Além de retratar a cidade, Herbster propôs sua expansão, elaborando cintas de avenidas, circulando o espaço urbano habitado, configurados através dos boulervards do Imperador, Duque de Caxias (logo prolongada para leste), e da Conceição (atual Avenida Dom Manuel), que comporia as vias de acesso à cidade, estabelecendo um modelo secção de vias urbanas em voga até os dias atuais. Dessa forma, percebe-se que Herbster desprezou 0 arruamento proposto por Simões de Farias em 1850, evitando cortar o Pajeú em trechos centrais, já ocupados por residências.

A proposta de expansão de Fortaleza por Herbster fez-se, portanto, pela continuação da Avenida Duque de Caxias, atual Avenida Heráclito Graça. Essa solução visava contornar o riacho cruzando pela Avenida Dom Manuel e suas paralelas, em trechos já distantes da foz.

\footnotetext{
2 Fortaleza passa de uma população estimada em 1500 habitantes em 1800, para 16000 habitantes em 1863 e a $21872 \mathrm{em}$ 1872.
}

Geografia Ensino \& Pesquisa, v. 15, n.1, p. 71-84 jan./abr. 2011

Fábio de Oliveira Matos

ISSN 2236- 4994 
3 É importante ressaltar que mesmo com o Passeio Público estando voltado em direção ao mar, isso não leva a crer numa possível tomada de consciência da sociedade para o mar, já que o andar em que se encontrava mais próximo da praia era reservado aos pobres e miseráveis (0 Passeio Público possuía três andares representados pelas classes sociais da época).

Geografia Ensino \& Pesquisa, v. 15, n.1, p. 71-84 jan./abr. 2011

A cidade e o mar: considerações sobre a memória das relações entre Fortaleza e o ambiente litorâneo
Essa nova proposta de expansão da cidade para o sul e para o leste, reforçava 0 desinteresse de fixação de moradia na faixa de praia pela classe abastada. Nesse período, algumas das mais importantes edificações da cidade foram se instalando próximo ao Forte de Nossa Senhora da Assunção. $O$ passeio Público, a Santa Casa de Misericórdia, a Penitenciária e a Estação da Estrada de Ferro terminaram por formar uma barreira entre a cidade e o mar, afirmando 0 desinteresse de uma possível urbanização do litoral. 0 acesso à praia tornava-se mais difícil, já que somente o Passeio Público ${ }^{3}$ tinha suas vistas voltadas para o mar.

$O$ desinteresse dado pela faixa praiana fortalezense resultava na distribuição de serviços insalubres instalados próximos à zona costeira, como o velho Paiol da Pólvora, o Gasômetro, dos tempos da iluminação a gás (1867), a Santa Casa de Misericórdia, bem como o depósito de lixo da cidade. 0 espaço entre 0 mar e essas edificações, passou a ser ocupado pelo comércio de exportação, próximo ao desembarcadouro e o Arraial Moura Brasil, formado pela população sertaneja foragida da seca.

Nesse contexto, é criado o Código de Posturas, vindo em confluência com as preocupações de ordem higienistas e urbanísticas que tinham por objetivo salvaguardar o decoro, a moral e os bons costumes dados à explosão demográfica decorrente do êxodo rural naquele período. Essa legislação reforçava o desinteresse pela zona de praia, ao afirmar, por exemplo, a regulamentação de que os dejetos fecais não poderiam ser despejados nas ruas, mas sim na Praia do Porto das Jangadas, denominação antiga da Praia de Iracema.

Tornava-se evidente o desinteresse do litoral por parte da elite da cidade, de natureza interiorana. Mesmo com os discursos médicos afirmando dispor o litoral fortalezense de excelentes condições climáticas para o tratamento de doenças respiratórias, os abastados ainda não se voltavam para o mar.

A partir do século $X X$, com movimento de tomada de consciência no domínio da literatura, permitiu-se incorporação lenta e gradual das praias, notadamente com a adoção de novas práticas marítimas surgidas na Europa: os banhos de mar, as caminhadas na praia e 0 veraneio. A considerável faixa de praia de Fortaleza passa a ser o novo ponto de encontro da cidade, além de despertar o interesse dos veranistas mais abastados.

Este lento movimento da cidade em direção à zona costeira cresce no tempo, com a incorporação gradual e progressiva de áreas anteriormente ocupadas por populações pobres, gerando conflitos entre as camadas da sociedade fortalezense, suscitando a expulsão da classe menos abastada. Em Fortaleza constitui-se este movimento no início do século XX, com a descoberta da Praia de Iracema como área de lazer e veraneio.

\section{Fortaleza descobre o mar}

A valorização do litoral como parte integrante da cidade é algo recente na história do desenvolvimento de Fortaleza. A relação da cidade com o litoral surge a partir da instalação do Porto nas intermediações da Praia do Peixe (atual Praia de Iracema). Porém, a presença dos moradores mais abastados era evitada, por ser ocupada pela população de baixa renda.

Além disso, Silva (1992) afirma que a localização da zona de meretrício nas redondezas do Porto, e a ocupação das dunas que margeiam o litoral em direção norte/nordeste por favelas foram, sem dúvida, fatores que levaram durante algum tempo ao desinteresse dos fortalezenses pelo litoral com a finalidade de aí se fixar. 
Aos poucos o imaginário social dos fortalezenses sobre o mar é modificado em virtude das descobertas de novas práticas marítimas. No Meireles são criados sítios para 0 tratamento da tuberculose. Uma outra prática marítima diz respeito às serenatas realizadas sobre as dunas próximas a área central da cidade.

Porém, as práticas marítimas citadas não foram capazes de possibilitar a litoralização da zona de praia de Fortaleza, pois o tratamento da tuberculose não aconteceu exclusivamente no litoral e as serenatas eram atividades pontuais de lazer.

Somente com a descoberta de novas práticas marítimas, como os banhos de mar, que 0 litoral passa a ser valorizado como lugar de lazer. Este movimento de valorização do litoral muda o olhar da elite de Fortaleza em relação à zona de praia, notadamente a Praia de Iracema, que deixa de ser o lugar da simples contemplação e adquire maior importância com os banhos de mar. Este movimento definirá uma nova caracterização social, demográfica e urbanística desta zona, com o deslocamento da população e a mudança dos usos, resultante da presença de veranistas.

Com a descoberta dessas novas práticas marítimas, a Praia de Iracema passa a competir com outras áreas de lazer da cidade, como a Praça do Ferreira e o Passeio Público. A Praia passa a ser o lugar da sociabilidade por excelência. Um paradigma de alteridade tão forte que sobrepõe a lógica da centralidade do plano em xadrez de Herbster, reconstruindo a cidade torno de uma auto-referência do vivido social.

Um fator determinante, que veio facilitar o deslocamento da população para aquela área foi a instalação da linha de bonde na Rua Tabajara em 1927, ligando a Praia de Iracema a área central da cidade, consolidando aquela zona de praia como área de lazer e veraneio.

Um marco do início da fixação de moradia da elite é a construção da residência "Vila Morena", atual Estoril, do comerciante pernambucano José Magalhães Porto, marcando 0 início da urbanização da área. Com a chegada da elite, vinda da área central da cidade, para a realização de práticas de lazer e veraneio na Praia de Iracema, a permanência da população de baixa renda passa a ser inviável, devido à especulação imobiliária, aumentando o valor do solo naquela área, gerando expulsão da população pobre.

Vale destacar, que a descoberta da praia pela elite não corresponderá a uma reorientação do crescimento de Fortaleza para as zonas de praia, pois se trata simplesmente de uma política pontual de urbanização da Praia de Iracema, em resposta à demanda da população das proximidades por banhos de mar. A partir da década de 1930 a elite passa a construir Bangalôs na Praia de Iracema para desfrutar melhor os banhos de mar. Este tipo de construção, próximo à zona de descanso das jangadas, mostra a influência da cultura europeia na cidade, expressada não somente na arquitetura, mas também nos hábitos da população.

Desde o final do século XIX, a Praça do Ferreira disputava com o Passeio Público à preferência de principal espaço de lazer da classe abastada fortalezense. Até a década de 1930 o entrono da Praça do Ferreira configurava-se como um reflexo da dinâmica da própria cidade, encontrando-se em seu entorno as mais diversas funções. Além dos edifícios representativos do poder público, do comércio, dos hotéis e do setor residencial, a função lazer se manifestava através dos cinemas, cafés e clubes. Porém, com a descoberta do mar pelos moradores mais abastados, estes passam a descobrir a praia como local de lazer e de deleite visual. No que concerne este processo de ocupação da orla marítima de Fortaleza, Rocha Júnior, (1984, p. 4) afirma:

Geografia Ensino \& Pesquisa, v. 15, n.1, p. 71-84, jan./abr. 2011

Fábio de Oliveira Matos 
A Praia de Iracema, até então local de "jogo de caipira, pinga e facada de pescada" adquire novas funções urbanas. A Praia, constituída por jangadeiros com suas casas de palha, com suas areias muito limpas e repletas de coqueiros, desperta a cobiça dos urbanistas mais abastados. Um dos primeiros foi o coronel Porto, comerciante vindo de Recife, que em 1926 inaugura o seu palacete eclético, onde hoje funciona o restaurante Estoril. Em torno da casa dos Portos, novos pequenos palacetes se levantam, formando aos poucos um ensaio de feição eclética onde se destacam os telhados de telha francesa $[. .$.

Essa afirmação evidencia que aos poucos alguns equipamentos de lazer passam a se instalar na faixa litorânea. Já em 1929, o clube Náutico Atlético Cearense tinha sua primeira sede instalada na Praia Formosa, nas imediações da Ponte Metálica. Ao mesmo tempo em que a Praia de Iracema marcava o inicio de sua trajetória como ponto de encontro e recreação da cidade.

Destacando este momento de incremento de equipamentos de lazer, destaca um antigo morador da área, o Senhor Ozarias Ferreira Lima ${ }^{4}$, de 91 anos:

Na Praia de Iracema surgiu muita coisa bonita, surgiram muitos balneários naquela época, eles eram ótimos para o fim-de-semana. Balneário naquela época [1944] eram os locais onde se guardava as roupas e os objetos pessoais, deixava dentro de uma caixa de madeira numerada e descia para a praia. No fim do dia ia lá tomar banho para tirar o sal do corpo, pois lá tinha várias duchas. No período da Guerra, quando o Estoril era para a diversão dos americanos, surgiram vários bares e restaurantes no entorno dele. Havia o Bar São Jorge que mesmo tendo fama de ser meio perigoso [...], atraía gente de todo canto de Fortaleza, principalmente o pessoal que morava ou trabalhava pelo Centro.

Era visível que a Praia de Iracema vivia seu período áureo. A Praia passa a ser destacada na música e na literatura dado o modo como se inseriu no cotidiano da cidade, Ozarias Ferreira destaca também que:

${ }^{4}$ Entrevista realizada no dia 27 de Outubro de 2010.

Geografia Ensino \& Pesquisa, v. 15, n.1, p. 71-84 jan./abr. 2011

A cidade e o mar: considerações sobre a memória das relações entre Fortaleza e 0 ambiente litorâneo

As jangadas da Praia dos Amores passaram a ter que concorrer espaço na praia com os bangalôs e bares que surgiam a toda parte. Na Ponte Metálica só chegava agora navios enormes, por causa da Segunda Guerra. E quando esses navios chegavam era uma festa, pois como os navios não atracavam na ponte, os jangadeiros eram chamados para ajudar a ir pegar o pessoal que vinham nos navios. A Praia realmente atraía muita gente. A Senador Pompeu e a Barão do Rio Branco eram as ruas que mais facilitavam o acesso dos que estavam no Centro pro o Mar. Pela manhã tinha os banhos na praia e as peladas, eu mesmo era do time da rua Dragão do Mar, porque o futebol já era muito popular naquela época, naquela região da Praia tinha o time do América, que era um dos grandes da cidade. A Ponte Metálica além de servir pro porto servia também pra pesca, além de ser muito bom para dar saltos no mar. Naquele tempo não havia essa história de surf por aqui não, a moda era brincar de carretilha, onde a gente pegava um bom pedaço de madeira e ficava deitado nela deslizando nas ondas. A noite tinha as serestas, que varavam a madrugada. Tudo só começou a piorar quando surgiu os quebra-mares, que arrasou com a Praia, no começo não foi tão ruim, porque tinha um quebra-mar que formava uma grande poça d'água quando a maré subia, que a gente chamava de Piscininha. 
A área do Poço das Dragas, destacado por ser uma área de meretrício de Fortaleza, é destacada pela Senhora Maria José Ferreira Lima ${ }^{5}, 88$ anos, como um local com pontos de lazer:

\begin{abstract}
Apesar do Poço das Dragas ser esquecido ou deixado de lado por muita gente, acho que pelo fato de as cinzas das caldeiras da Light serem jogadas lá, ia muita gente, ou que morava na Barão do Rio Branco ou que trabalhava na RVC ${ }^{6}$, já que estes tinham mais contato por lá, pois vendiam lenha tanto para a Light quanto para as mulheres que moravam no Curral das Puta. Esse pessoal aproveitava a maré baixa para brincar um pouco na praia, principalmente jogar futebol. A Praia do Paredão, como algumas pessoas chamavam aquela região por causa de um enorme muro construído contornando o estaleiro, nunca atraiu muita gente, mas quem queria encontrava diversão.
\end{abstract}

Porém, o uso da Praia de Iracema para as práticas marítimas é efêmero, pois com a transferência do Porto do Poço das Dragas para o Mucuripe, além de resultar no abandono e consequente deterioração dos armazéns das Dragas, provocou uma série de problemas ambientais, tendo a área preferencial para banho na Praia de Iracema sendo violentamente atingida pela corrente da costa, resultando na erosão da praia. A privilegiada paisagem praiana é destruída (Figura 5), resultando apenas pequenos trechos da praia com balneabilidade.

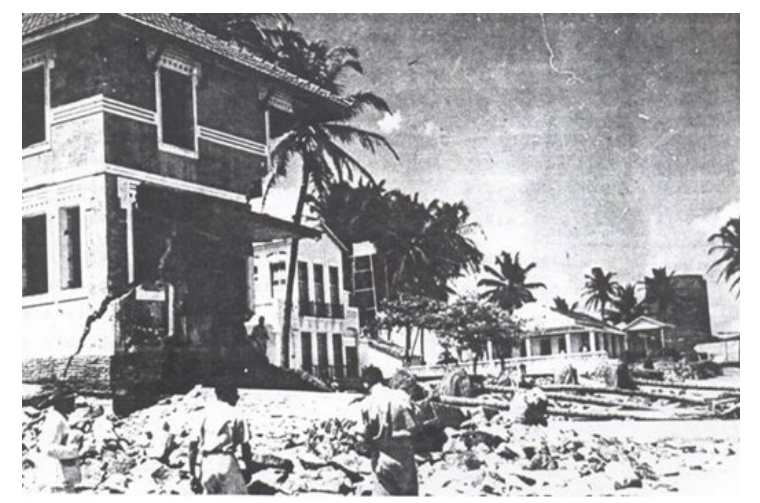

Figura 5 - Destruição da área próxima ao restaurante Estoril-1955 Fonte: Arquivo Nirez.
Os abastados vão buscar na periferia, notadamente a zona leste da cidade, área para lazer e moradia. A respeito das práticas marítimas e a decadência ocorridas na Praia de Iracema entre as décadas de 1940 a 1950, nos relata um ex-morador do bairro, Walter Matos $^{7}$, de 74 anos:

A Praia de Iracema era uma área muito dinâmica pro lazer. Havia inicialmente maioria de homens, que iam para aquela área em busca de prostitutas, era uma espécie de Passeio Público daquela época. Com o passar do tempo, as mulheres de família passaram a frequentar a Praia dos Amores, só que homens e mulheres tomavam banho em lugares distintos, era falta de respeito um homem tomar banho com a mulher da frente de todo mundo. A Praia de Iracema atraía muita gente do Centro da cidade, pois como o Poço das Dragas, que era pra ser a praia da população do Centro estava quase que todo ocupado com as atividades do Porto, não dava para tomar banho de mar. Principalmente nos finais de semana, o bonde Praia de Iracema, que saía da Praça do Ferreira e ia até a Igrejinha da Praia de Iracema, vinha lotado de gente vinda do Centro que
${ }^{5}$ Entrevista realizada no dia 13 de Novembro de 2010.

6 Rede de Viação Cearense, posteriormente intitulada REFFSA - Rede Ferroviária Federal Sociedade Anônima.

${ }^{7}$ Entrevista realizada no dia 13 de Janeiro de 2011

Geografia Ensino \& Pesquisa, v. 15, n.1, p. 71-84 jan./abr. 2011

Fábio de Oliveira Matos

ISSN 2236- 4994 81 
queria passear pela praia, era moda naquela época. Esta ficando tão famosa quanto a Praça do Ferreira. Quando eu era pequeno, ia a Praia para brincar na Piscininha, um espelho de água do mar formado por um paredão de pedra que ficava próximo ao Estoril. Era tudo muito divertido. Pegávamos um pedaço de madeira e íamos brincar de carretilha na Piscininha, deslizando na água. 0 ponto de encontro das crianças naquela praia era aquele lugar. Por falar em Estoril, ele tinha uma função muito diferente do que é hoje em dia. Ele servia naquela época como ponto de encontro dos marinheiros americanos no período da $2^{\mathrm{a}}$ Guerra Mundial. Todo mundo queira ir lá conhecer eles, pois não era todo dia que aparecia tanta gente vinda de longe com notícias sobre a Guerra, porque as notícias demoravam muito para chegar por aqui, só tínhamos o rádio para saber das novidades no mundo. Tinha gente que dizia ver submarinos e bombas dos alemães na Paria de Iracema. A Praia de Iracema era um lugar muito bom de viver, pena que durou pouco. Muita gente ficou assustada com a força do mar um tempo depois que retiraram o Porto do Poço das Dragas para colocar na Ponta do Mucuripe. As casas da Praia de Iracema que eram muito bonitas, parecendo aquelas que víamos em fotos da Europa, foram todas destruídas pelas ressacas do mar, a Piscininha sumiu e a parte de areia também.

Com a decadência da Praia de Iracema, em meados da década de 1950, favorecida pela ação erosiva e a consequente instalação de quebra-mares (ver Figura 7), e do Centro da cidade, devido a mesma ter ficado a margem do processo de expansão urbana que Fortaleza vinha passando nesses últimos decênios, registrando desvantagens locacionais de grande porte e acentuado isolamento do restante da cidade.
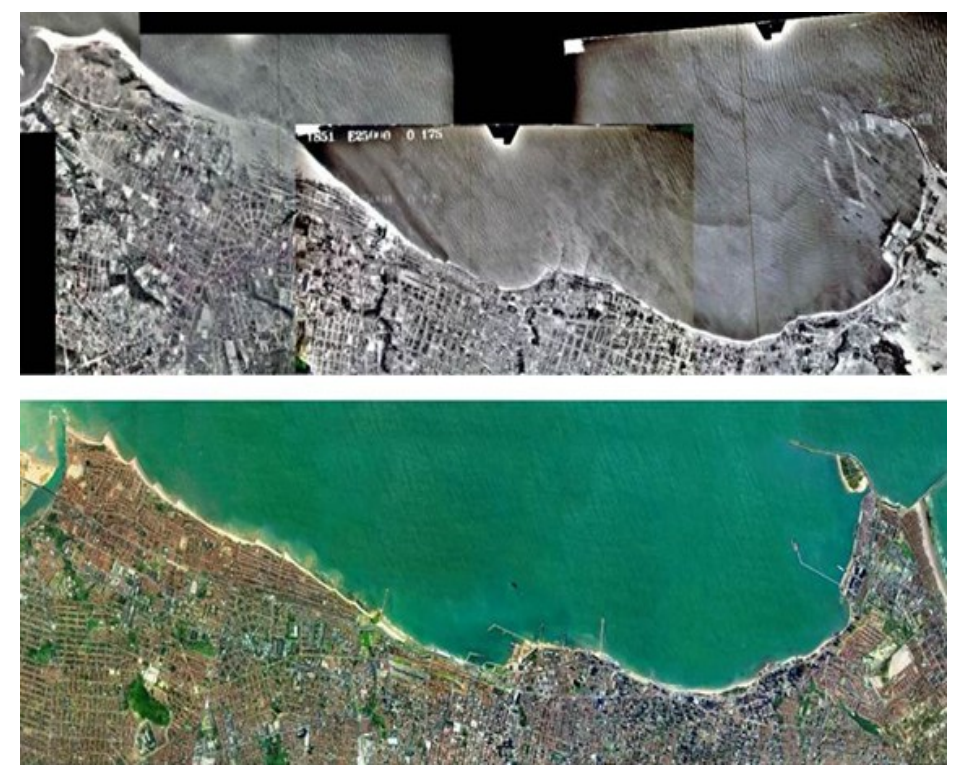

(abaixo).

Figura 7 - Perfil comparativo do ambiente costeiro em Fortaleza nas décadas de 1950 (acima) e na atualidade

Geografia Ensino \& Pesquisa, v. 15, n.1, p. 71-84 jan./abr. 2011

A cidade e o mar: considerações sobre a memória das relações entre Fortaleza e o ambiente litorâneo
Fonte: Arquivo Nirez e Google Earth.

A Praia e 0 a área central de Fortaleza passam por intensa degradação estrutural, como a falta de pavimentação das ruas, sistema de esgotamento sanitário e coleta regular de lixo. Essa decadência proporcionou a construção de uma imagem negativa da área. Além da perda do dinamismo recreativo, a praia de Iracema perde sua função econômica. A instalação do porto do Mucuripe resultou também na estagnação do comércio da área em frente ao 
núcleo central, com o deslocamento dos armazéns e depósitos para as novas docas. Era mais uma etapa no processamento da paisagem litorânea pelo qual passava a praia de Iracema.

Banhistas, clubes e restaurantes ao buscarem ouras praias, traziam de modo mais visível o processo de diferenciação espacial e a segregação residencial pelo qual passa a cidade. Sem a praia do lazer do catraieiro do porto e do prazer dos ricos, passava a ocorrer de modo mais intenso fato semelhante ao que ocorria no espaço urbano de Fortaleza, tendo a partir daquela situação a efetivação das praias dos ricos e dos pobres, distribuindo a população pelo nível de renda.

A partir da década de 1970 a Praia de Iracema, através de movimento iniciado na Europa, passa a se fortalecer enquanto área de exaltação as artes e a boemia, com hábitos especificamente noturnos. Essa nova utilização do espaço intensifica-se a partir dos anos 1980, por meio da instalação de variados restaurantes, dando uma dimensão mais comercial e nova dinâmica para a área, diferenciando-se do domínio residencial da década de 1950. Entre essas novas instalações o Pirata Bar, inaugurado em 1986, ganha destaque nacional, com a promoção de festas às segundas-feiras, tendo como principal atração o forró. As festas passam a ter grande divulgação, aumentando o fluxo de turistas para a Praia de Iracema.

$\mathrm{Na}$ década de 1990, novos equipamentos paisagísticos e de lazer da cidade, como a reforma da Ponte dos Ingleses, o calçadão e o Centro Dragão do Mar surgem no contexto de revalorização da Praia de Iracema, reconfigurando um cenário urbano com o objetivo de espetacularização com vistas ao turismo.

Nesses períodos mencionados, a área central de Fortaleza passa a amargar um expressivo abandono em suas atividades, pois estas eram voltadas para uma demanda populacional que passa a não mais frequentar a área. Com a não permanência de moradores mais abastados, devido o mesmo passar a ter uma função social voltada agora predominantemente para as atividades comerciais da classe menos abastada, se tem uma cisão entre esta área com as práticas marítimas.

\section{Considerações Finais}

A pesquisa buscou analisar os eventos históricos de Fortaleza frente às práticas marítimas na Praia de Iracema, apresentando as mudanças de usos da Praia no contexto de evolução urbana da cidade. Frente a essa análise, emerge uma discussão a respeito da requalificação urbana da zona litorânea de Fortaleza na atualidade, incorporando-a no roteiro turístico do Estado.

Nesse contexto, destacamos o cenário da Praia de Iracema, que passa a ser frequentada por boêmios, após o abandono da elite. Hoje, a referida praia se configura como centro receptor dos principais equipamentos paisagísticos e de lazer da cidade, como a Ponte dos Ingleses, o Estoril e o Centro Dragão do Mar. A instalação destes equipamentos que hoje redesenham a Praia de Iracema objetiva a mutação do conteúdo social e econômico da área, com o Centro Dragão do Mar, que se enquadra na perspectiva de um projeto que pretende articular turismo, renovação urbana e política cultural.

A construção deste centro cultural enquadra-se nas ações do Estado que visa a requalificação desse importante espaço histórico da capital, o que contribui para a ampliação

Geografia Ensino \& Pesquisa, v. 15, n.1, p. 71-84, jan./abr. 2011

Fábio de Oliveira Matos 
da imagem turística da cidade, transformando Fortaleza em centro receptor de turismo no Ceará.

\section{Referências}

BARROSO, Gustavo. Terra do sol: natureza e costumes do Norte. Rio de Janeiro: Benjamim Aguila, 1912.

CASTRO, José Liberal de. Uma planta fortalezense de 1850 reencontrada. Revista do Instituto do Ceará. Fortaleza, Ceará, v. 119, p. 107-153, 2005.

COSTA, Maria Clélia Lustosa. Fortaleza: expansão urbana e organização do espaço. In: SILVA, José Borzacchiello da; DANTAS, Eustógio Wanderley Correia; CAVALCANTE, Tércia. Ceará: um novo olhar geográfico. Fortaleza: Edições Demócrito Rocha, 2005.

DANTAS, Eustógio Wanderley. Mar à vista: estudo da maritimidade em Fortaleza. Fortaleza: Museu do Ceará/Secretaria de Cultura e Desporto do Ceará, 2002.

KOSTER, Henry; CASCUDO, Luis da Câmara. Viagens ao nordeste do Brasil. Recife: Fundação Joaquim Nabuco/ Massangana, 2002.

LINHARES, Paulo. Cidade de água e sal: por uma antropologia do litoral do Nordeste sem cana e sem açúcar. Fortaleza: Fundação Demócrito Rocha, 1992.

LEMENHE, Maria Auxiliadora. As razões de uma cidade: conflito de hegemonias. Fortaleza: Fundação Demócrito Rocha, 1992.

ORIÁ, Ricardo; JUCÁ, Gisafran. De Fortaleza à vila e cidade (1603-1889). In: PREFEITURA Municipal de Fortaleza. Fortaleza, a gestão da cidade: uma história político-administrativa. Fortaleza: Fundação Cultural de Fortaleza, 1994.

ROCHA JÚNIOR. Antônio Martins da. 0 turismo globalizado e as transformações urbanas do litoral de Fortaleza: arquitetura e estetização na Praia de Iracema. 2000. Dissertação (Mestrado em Desenvolvimento e Meio Ambiente) - Universidade Federal do Ceará, Fortaleza, 2000.

SILVA, José Borzacchiello da. Quando os incomodados não se retiram: uma análise dos movimentos sociais em Fortaleza. Fortaleza: Multigraf editora, 1992.

SOUZA, Maria Salete. O crescimento das cidades no Ceará e sua evolução. In: SIMPÓSIO Nacional de Geografia Urbana, 4., 1995, Fortaleza. Anais do IV Simpósio Nacional de Geografia Urbana. Fortaleza: NUTEC, 1995, p. 105-111. 